\title{
Organoleptic evaluation of Archachatina marginata fed rumen content dietary
} inclusion

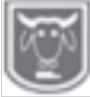

Raimi, C. O. and Odeyemi, A. C.

Department of Agriculture, Federal Polytechnic, P.M.B.5351, Ado-Ekiti

Corresponding author: christosinr@gmail.com; 08102256197

\section{Abstract}

There is inadequate information on quality feedstuff for large scale production and all year round availability of snails in Nigeria.The research was conducted to investigate the organoleptic properties of the African giant land snails (Archachatina marginata). Thirtytwo snails were randomly allotted into four dietary treatments of varied levels of $0 \%, 5 \%$, $10 \%$ and $15 \%$ rumen content inclusion. Each treatment was replicated with four snails per pen in a completely randomized design. The snails were reared in mini paddock. Feed and water were supplied ad-libitum. At the end of the eight weeks period of feeding trials, two snails were harvested at random from the replicates of each of the four treatments, sacrificed, processed and analyzed. Based on appearance, taste and aroma of the snails fried and stewed with spices and the other one steamed with spices, preference ranking in descending order revealed 15\% (6.85) rumen content inclusion had the highest mean preference followed by 5\% (6.53) inclusion for the fried snail with spices and 0\% (6.65) inclusion had the highest ranking followed by 15\% (6.53) rumen content inclusion for the snail steamed with spices. The treatments had no appreciable effect on the nutrient composition and sensory quality of the snail meat. It can be concluded that growing snails can utilize rumen content inclusion thereby increasing the feed data base for snail production in the Tropics.

Keywords: rumen contents, Archachatina marginata snails, sensory evaluation, feed per grain

\section{Introduction}

The giant African land snails (Archachatina marginata) are distributed all over the humid tropical zones of Africa and it is one of the most important minor forest products in West Africa and Nigeria in particular (Akinnusi et al., 2014). Snail production serves as cheap source of animal protein supply which makes it comparable with other conventional protein sources. Archachatina marginata eat a wide range of feed but prefer herbs and vegetables; they also compete with man for his available vegetables. To prevent unwholesome competition, non-conventional alternate sources of rich feed for snail and other livestock has become area of concentration for scientific researchers in recent times. Some snails' specie can aestivate for as long as many months without food and water under aestivation (Akinnusi et al., 2014). Aestivation plays a critical role in dynamics of haemolymph which is an important medium for the transport of nutrients and waste to various organs of land snail. (Babalola et al., 2009) reported that the flesh and haemolymph of snails are rich in $\mathrm{Ca}^{2}, \mathrm{Mg}+, \mathrm{Na}+, \mathrm{Zn}+, \mathrm{Fe}^{2}+$, and Cl-. The ionic and organic composition of snails shell and epiphragm increased during aestivation while that of the haemolymph were decreased (Ajayi et al., 2012). The aestivated snail draw on the reserve of fat and glycogen at much reduced rate, which implies the imminent reduction in weight, and loss of valuable growing time during aestivation is reduced (Abdulssamad et al., 2010). Snails are also good converter of vegetable protein to useful animal protein. They provide a cheap source of highquality animal protein for human consumption. Snail farming is also a high profit-yielding venture and requires less capital when compared to other livestock 


\section{Organoleptic evaluation of Archachatina marginata fed rumen content dietary inclusion}

farming. Thousands of land snails can be raised in a small land space if intensively managed and there is always less need for vaccination and therapeutic drugs. Moreover, predators, parasites and diseases can be prevented easily through proper management and hygienic conditions. However, the success of snail farming as well as the availability of snail meat all through the year is largely dependent on the availability of feeds. The availability of feeds is one of the major problems in many livestock productions including snail. Snails feed on leaves, vegetables, fruits as well as compounded feeds and kitchen wastes. Most conventional feedstuffs used in compounding the feed like maize, sorghum, soybeans and guinea corn are very costly and have high human preference and demand (Cowie et al., 2009).

\section{Materials and methods}

Thirty-two healthy growing Archachatina marginata with initial average weight of $240 \pm 0.02 \mathrm{~g}$ were allocated to four dietary treatments of varied levels of $0 \%, 5 \%, 10 \%$ and $15 \%$ rumen content inclusion. Each treatment was replicated with four snails per pen in a completely randomized design. The snails were reared in mini paddock. Feed and water were supplied ad-libitum. The snails $\mathrm{T}_{1}$ were fed with $(0 \%) ; \mathrm{T}_{2}(5 \%)$; $\mathrm{T}_{3}(10 \%)$ and $\mathrm{T}_{4}(15 \%)$ rumen content inclusion respectively. After the eight weeks feeding trial, two snails from each of the treatment were harvested, sacrificed, eviscerated and properly cleaned in the department of Food Technology Laboratory. The sacrificed snails were carefully de-shelled to expose the fresh and intact edible flesh, which was washed with clean water and then fried and steamed with spices. Sensory evaluation (preference and palatability trial) of edible snail were determined, two sets of the same snail meat were prepared in 10 minutes each with one set fried and stewed with spices, and the other set was steamed with spices. After preparation, one set was presented to each of the 20 "taste panelists" in a saucer at a time using the "cafeteria method". Twenty taste points (replications) having the four pieces of snail meat representing the four treatment groups were presented to the panelists. A preliminary instruction session was conducted between the researcher and the "taste panelists" prior to the commencement of the preference and palatability trial. They were instructed to avoid conversations and discussions during sensory evaluation sessions. Sensory evaluation score sheets (Questionnaires) were given to the panelist for rating of the samples according to standard procedure measure. The ratings were based on a 9 point hedonic scale of 1(dislike extremely) and 9(like extremely). The evaluation was based on appearance, taste, aroma and overall acceptability. A maximum score of 4 points was awarded for the best parameter and a least score of 1 point awarded to the worst parameter, respectively using the methods described by AMSA (1995). All data in each parameter were subjected to one-way analysis of variance to determine if there was any significant difference due to the type of feed used. Duncan Multiple Range test was applied to separate means of significantly differed parameters. All statistical analyses were done using SPSS version 15 .

\section{Results and discussion}

The results of the proximate composition of the experimental feed are presented in presented in Table 1. The protein content of snail meat varied $(p<0.05)$ with changes in the levels of the rumen content. Snail meat containing the $15 \%$ rumen content inclusion had a higher crude protein that 


\section{Raimi and Odeyemi}

was significantly different $(\mathrm{p}<0.05)$ from those of other combinations. The carbohydrate in snail meat was affected $(p<0.05)$ by levels of the rumen content inclusion. The carbohydrate content in snail meat containing $0 \%$ rumen content inclusion had higher $(\mathrm{p}<0.05)$ carbohydrate than other treatments. Snail meat containing $0 \%$ rumen content level had higher $(\mathrm{p}<0.05)$ moisture content than other treatments. The crude fat in snail meat differ $(p<0.05)$ among the treatment levels. The 10\% rumen content inclusion had higher $(p<0.05)$ crude fat that was significantly different from those of other treatments. Also, Ash of the snail meat was influenced $(p<0.05)$ by the treatment levels. $0 \%$ rumen content inclusion level had higher $(p<0.05)$ Ash content than other treatment. Snail meat containing 5\% rumen content level had higher $(p<0.05)$ crude fibre than other treatments. The crude fibre in snail meat differ $(\mathrm{p}<0.05)$ among the treatment levels.

Table 1: Proximate composition of meat of snail fed different experimental diets

\begin{tabular}{cccccc}
\hline & Control 0\% & \multicolumn{5}{c}{ Level of replacement } & \multicolumn{1}{c}{} & \\
\hline Moisture(\%) & $69.74^{\mathrm{a}}$ & $67.87^{\mathrm{b}}$ & $65.03^{\mathrm{d}}$ & $66.27^{\mathrm{c}}$ & \multicolumn{1}{c}{$\mathbf{1 5 \%}$} \\
& & & & & 0.44 \\
Protein (\%) & $21.10^{\mathrm{d}}$ & $24.17^{\mathrm{c}}$ & $25.07^{\mathrm{b}}$ & $26.12^{\mathrm{a}}$ & 0.31 \\
& & & & & \\
Fat (\%) & $1.96^{\mathrm{b}}$ & $1.27^{\mathrm{c}}$ & $2.40^{\mathrm{a}}$ & $0.91^{\mathrm{d}}$ & 0.20 \\
Ash (\%) & $6.19^{\mathrm{a}}$ & $5.17^{\mathrm{c}}$ & $5.81^{\mathrm{b}}$ & $3.18^{\mathrm{d}}$ & 0.27 \\
Fibre (\%) & $8.60^{\mathrm{d}}$ & $12.01^{\mathrm{a}}$ & $11.97^{\mathrm{b}}$ & $11.17^{\mathrm{c}}$ & 0.42 \\
CHO (\%) & $2.83^{\mathrm{a}}$ & $2.62^{\mathrm{c}}$ & $2.68^{\mathrm{b}}$ & $2.63^{\mathrm{c}}$ & 0.12 \\
\hline
\end{tabular}

SEM-Standard Error of Mean

Table 2 showed the sensory evaluation of the varied level of dietary treatments (fried snail meat). The dietary treatments had no significant effect on the appearance, taste, aroma and overall acceptability of the snail meat (Table 2). From the results, 15\% rumen content inclusion had the highest preference followed by $5 \%$ inclusion. In terms of appearance, 15\% (7-15) inclusion had the highest ranking followed by $5 \%$
(6.55) inclusion. In terms of taste, $15 \%$ (6.55) inclusion also had the highest ranking followed by $10 \%(6 \cdot 40)$ inclusion. For Aroma, 5\% (6.60) inclusion had the highest ranking followed by $10 \%(6 \cdot 20)$ inclusion. In conclusion, mean overall acceptability showed that $15 \% \quad(6 \cdot 85)$ inclusion had the highest ranking followed by $5 \%(6 \cdot 53)$ inclusion.

Table 2: Organoleptic properties of Fried snail meat fed varied level of Rumen content inclusion

\begin{tabular}{lccccc}
\hline Quality Attributes & $\mathbf{T 1}$ & $\mathbf{T 2}$ & $\mathbf{T 3}$ & $\mathbf{T 4}$ & SEM \\
& $\mathbf{0 \%}$ & $\mathbf{5 \%}$ & $\mathbf{1 0 \%}$ & $\mathbf{1 5 \%}$ & \\
\hline Appearance & & & & \\
Taste & $6 \cdot 25^{\mathrm{d}}$ & $6 \cdot 55^{\mathrm{b}}$ & $6 \cdot 35^{\mathrm{c}}$ & $7 \cdot 15^{\mathrm{a}}$ & 0.25 \\
Aroma & $5 \cdot 80^{\mathrm{c}}$ & $5 \cdot 85^{\mathrm{c}}$ & $6 \cdot 40^{\mathrm{b}}$ & $6 \cdot 55^{\mathrm{a}}$ & 0.24 \\
Overall Acceptability & $6 \cdot 00^{\mathrm{d}}$ & $6 \cdot 60^{\mathrm{a}}$ & $6 \cdot 20^{\mathrm{b}}$ & $6 \cdot 10^{\mathrm{c}}$ & 0.24 \\
Mean & $6 \cdot 75^{\mathrm{d}}$ & $7 \cdot 10^{\mathrm{b}}$ & $7 \cdot 00^{\mathrm{c}}$ & $7 \cdot 60^{\mathrm{a}}$ & 0.33 \\
Preference Ranking & $6 \cdot 20^{\mathrm{c}}$ & $6 \cdot 53^{\mathrm{b}}$ & $6 \cdot 49^{\mathrm{b}}$ & $6 \cdot 85^{\mathrm{a}}$ & 0.26 \\
\hline
\end{tabular}

SEM - Standard Error of Means 


\section{Organoleptic evaluation of Archachatina marginata fed rumen content dietary inclusion}

Table 3 showed the sensory evaluation of the dietary treatments (steamed snail meat). Likewise, the dietary treatments had no significant effect on the appearance, taste, aroma and overall acceptability of the snail meat (Table 3). From the results, it was revealed that $0 \%$ rumen content inclusion had the highest preference followed by $15 \%$ inclusion. In terms of appearance, $0 \%$ and $15 \%(6 \cdot 65 \%)$ rumen content inclusion had the highest ranking. In terms of taste $0 \%(6 \cdot 35)$ inclusion had the highest ranking followed by $15 \%(6 \cdot 30)$ inclusion. For aroma, 0\% (6.30) inclusion had the highest ranking. Conclusively, mean overall acceptability, showed that $0 \%$ inclusion (6.65) had the highest ranking followed by $15 \%$ (6.53) rumen content inclusion.

Table 3: Organoleptic properties of Steamed Snail meat fed varied level of Rumen content inclusion

\begin{tabular}{lccccc}
\hline Quality Attributes & T1 & $\mathbf{T 2}$ & $\mathbf{T 3}$ & T4 & SEM \\
& $\mathbf{0 \%}$ & $\mathbf{5 \%}$ & $\mathbf{1 0 \%}$ & $\mathbf{1 5 \%}$ & \\
\hline Appearance & $6 \cdot 65^{\mathrm{a}}$ & $6 \cdot 20^{\mathrm{c}}$ & $6 \cdot 40^{\mathrm{b}}$ & $6 \cdot 65^{\mathrm{a}}$ & 0.24 \\
Taste & $6 \cdot 35^{\mathrm{a}}$ & $5 \cdot 85^{\mathrm{c}}$ & $6 \cdot 20^{\mathrm{b}}$ & $6 \cdot 30^{\mathrm{a}}$ & 0.30 \\
Aroma & $6 \cdot 30^{\mathrm{a}}$ & $6 \cdot 20^{\mathrm{b}}$ & $6 \cdot 15^{\mathrm{c}}$ & $6 \cdot 20^{\mathrm{b}}$ & 0.29 \\
Overall Acceptability & $7.30^{\mathrm{a}}$ & $6 \cdot 85^{\mathrm{d}}$ & $7 \cdot 00^{\mathrm{b}}$ & $6.95^{\mathrm{c}}$ & 0.33 \\
Mean & $6.65^{\mathrm{a}}$ & $6 \cdot 28^{\mathrm{d}}$ & $6 \cdot 44^{\mathrm{c}}$ & $6.53^{\mathrm{b}}$ & 0.27 \\
Preference Ranking & $1^{\mathrm{st}}$ & $4^{\text {th }}$ & $3^{\text {rd }}$ & $2^{\text {nd }}$ &
\end{tabular}

\section{SEM - Standard Error of Means}

The proximate composition of the varied level of dietary treatments as shown in Table 1 proved that $15 \%$ rumen content inclusion in snail diets would be more nutritious based on the very high crude protein $(26.12 \%)$. This in agreement with Adeniji (2013) who reported crude protein $(22.22 \%)$ in snail diets fed $15 \%$ rumen content inclusion. Likewise, $15 \%$ inclusion had the highest value of $34 \mathrm{~g}$ of feed intake when compared with the control which had the least of $32 \mathrm{~g}$. The values recorded for ash content (3.18\%) in this study were higher than the 1.35 to $1.44 \%$ reported by others (Fagbuaro et al., 2006). The higher ash content in snail meat fed $15 \%$ inclusion may be attributed to the high amount of mineral availability in the feed through the natural feed ingredients. Recorded moisture content of the snails in this study were $65.03-69.74 \%$, this was lower than 76.56-78.65\% moisture content reported by other workers who investigated the nutritional status of four species of giant snails from the wild in Ekiti State, South
Western Nigeria (Fagbuaro et al., 2006). These variations may be attributed to the natural conditions to which the snails were exposed such as gaining regular access to natural succulent plants and rainfall. Moreover, the range $0.91-2.40 \%$ recorded in this study as fat content for the edible portion of the snail were similar to the range $0.9-1.5 \%$ reported for snails by other workers in Nigeria (Omole, 2007). Differences in diet type and weather conditions could be the major reason for the little differences.

This research was carried out on fried and steamed snail meat to ascertain the impacts of the diets utilized by these snails in their natural habitats based on their sensory or organoleptic qualities (appearance, taste, aroma) and how these parameters may influence the palatability and preference for snail meat by consumers. The findings of this study were similar to those obtained in an earlier experiment reported by Babalola and Akinsoyinu (2010) for snails fed the 


\section{Raimi and Odeyemi}

same set of experimental diets. This means that any of the feed could be used in feeding growing snails without adverse effect.

\section{Conclusions}

The inclusion of rumen content diets showed great increase in profit and gross profitability. In conclusion, throughout the experiment, 15\% Rumen Content inclusion is being recommended. Moreover, the experiment showed that increase in the level of Rumen Content by reducing the level of conventional feed stuff could reduce the cost of feed production. This result will be very beneficial to snail farmers by reducing their cost of production that would have accrued from high feed prices. In addition, it would help to meet consumers' demands in terms of providing the right nutrition, meeting daily intake of animal protein as well as providing necessary remediation to challenges of ill-health in man.

\section{References}

Abdussamad, M. A., Osinowo, O. A., Smith, O. F. and Onadeko, S. A. 2010. Some haemolymph biophysical parameters in Giant African Land Snails (Archachatina marginata) during six weeks aestivation period: Global Veterinarian 4 (4): 400-408.

Adeniji, A. A. 2013. Effects of feeding graded levels of rumen content meal on the performance of growing snails. BTAIJ, 7(4): 137141.

Ajayi, O.A., Fawole, J. K. Idowu, A. B. and Ademolu, K.O. 2012. Dynamics of nutrients in the tissues of Giant African Land Snail (Archachatina marginata) during aestivation. Proceedings of the $1^{\text {st }}$ Intl Confr. on Giant African Land Snails. Feb. 2012. Abeokuta, Nig. Pp 67-71.

Akinnusi, O. 2014. Snail production and management. Tolukoya publishing company, Abeokuta, Nigeria, 105 p.

AMSA 1995. Research guidelines for cookery, sensory evaluation and instrumental tenderness measurements of fresh meat. Chicago, IL: American Meat Science Association.

Babalola, O. O. 2009. Proximate composition and mineral profile of snail meat from different breeds of land snail in Nigeria. Pakistan journal of Nutrition 8(12): 18421844.

Babalola, O. O. and Akinsoyinu, A. O. 2010. Performance, carcass analysis and sensory evaluation of cooked meat of snailets of African giant land snail (Archachatina marginata) fed pawpaw leaves, whole lettuce, lettuce waste and cabbage waste as sole feed ingredient. African Journal of Agricultural Research Vol. 5(17): 2386-2391.

Cowie, R. H., Dillon, R.T., Robinson, D.G. and Smith J.W. 2009. "Allien non-marine snail and slugs priority quarantine importance in the United State; American malacological bulletin 27: 113 132.

Fagbuaro, O., Oso, J. A., Edward, J. B. and Ogunleye, R. F. 2006. Nutritional status of four species of giant land snail in Nigeria. $J$. Zhejiang Univ. Sci. B., 7:686-689. doi: 10.1631/jzus.2009.B0686.

Omole, A. J, Taiwo, A. A. and Amusan, J.A. 2007. Practical Snail Farming - Technical Guide / Bulletin, Institute of Agricultural Research.

Received: $20^{\text {th }}$ August, 2019

Accepted: $19^{\text {th }}$ December, 2019 